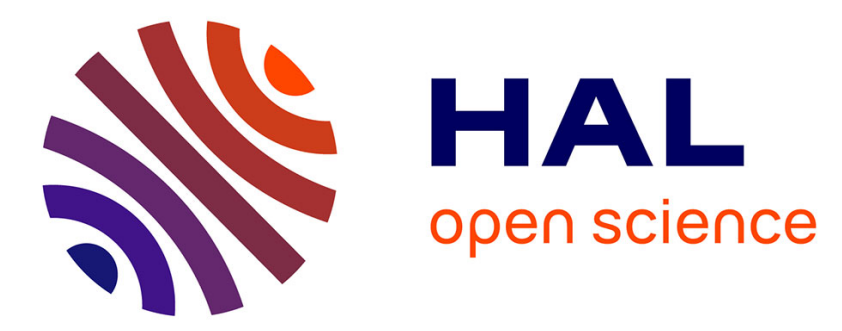

\title{
How to reduce uncertainties in a coupled and spatialized water quality model using data assimilation?
}

Emilie Rouzies, Claire Lauvernet, Arthur Vidard

\section{To cite this version:}

Emilie Rouzies, Claire Lauvernet, Arthur Vidard. How to reduce uncertainties in a coupled and spatialized water quality model using data assimilation?. vEGU21 - European Geosciences Union, Apr 2021, Vienne, Austria. pp.1. hal-03462057

\section{HAL Id: hal-03462057 https://hal.inrae.fr/hal-03462057}

Submitted on 1 Dec 2021

HAL is a multi-disciplinary open access archive for the deposit and dissemination of scientific research documents, whether they are published or not. The documents may come from teaching and research institutions in France or abroad, or from public or private research centers.
L'archive ouverte pluridisciplinaire HAL, est destinée au dépôt et à la diffusion de documents scientifiques de niveau recherche, publiés ou non, émanant des établissements d'enseignement et de recherche français ou étrangers, des laboratoires publics ou privés. 
Rouzies Emilie ${ }^{1}$, Lauvernet Claire ${ }^{1}$, Vidard Arthur $^{2}$

IINRAE, UR RiverLy, F-69625, Villeurbanne, France, ${ }^{2}$ INRIA, LJK, F-38000 Grenoble, France

Contact : emilie.rouzies@inrae.fr

Uncertainty quantification and reduction is necessary before considering operationnal use of any pesticide transfer model. In this study, we developed a framework for joint variable-parameter assimilation of satellite surface moisture images in the PESHMELBA model. A fairly simple virtual hillslope inspired from a realistic catchment is set up and data assimilation is performed on twin experiments.

\section{The PESHMELBA model (Rouzies et al., 2019)}

The PESHMELBA model simulates pesticide transfers and fate on small agricultural catchments.

- Explicitely considers the effect of discontinuities (hedges, ditches, rivers, filter zones) and the spatial organisation of the landscape

- Characterized by a modular structure that makes it possible to test different scenarios of agricultural/landscape management practices

- Process-oriented, fully spatialized model.

- One module $\equiv$ one process or ensemble of processes on a landscape element + coupling within the OpenPALM coupler (Buis et al., 2006)

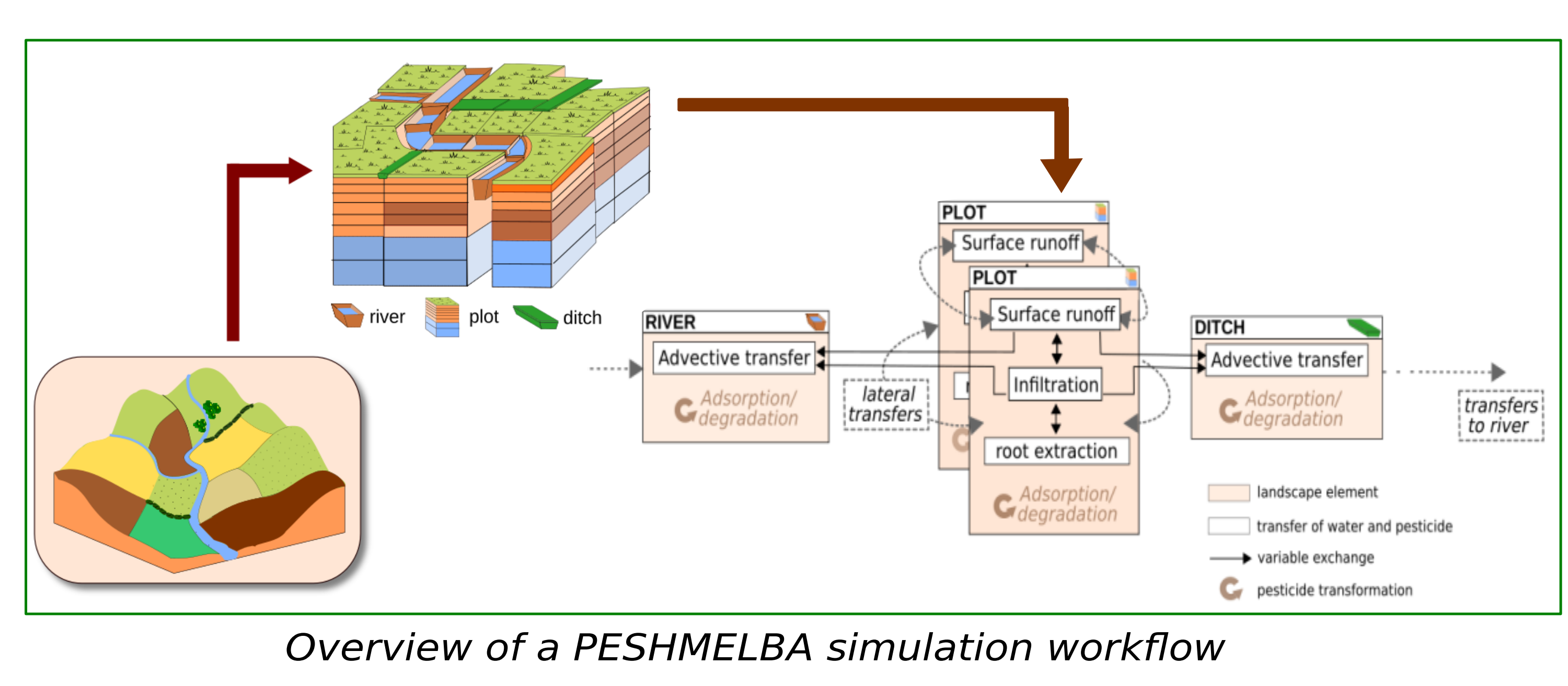

How to use data assimilation to quantify and coupled model ?

\section{Data assimilation set-up (twin experiments)}

- Available data : surface moisture images from Sentinel-2 Frequency : 5 days

Obs. error : $5 \%$ (Baghdadi and Zribi, 2016)

- Let's start simple: virtual simplified hillslope derived from La Morcille real catchment (France)

- Even simple: 3 heterogeneous soil types +3 landscape element types $=>145$ parameters

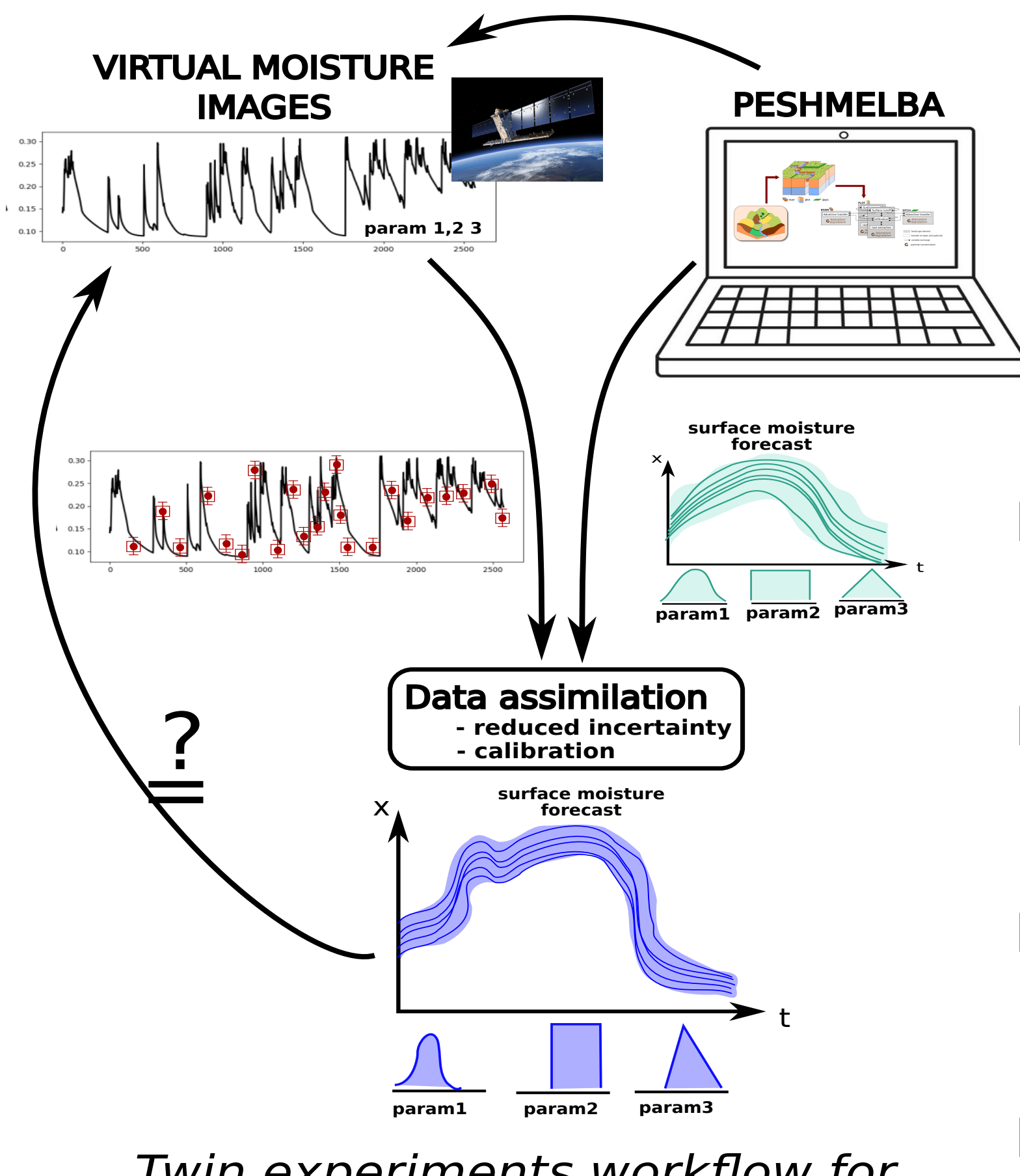

Twin experiments workflow for
assimilating surface moisture assimilating surface moisture
images in PESHMELBA

framework. It is compos to set up DA plots, vegetative filter zones and rivers.

Twin experiments: virtual moisture images generated from a reference PESHMELBA simulation. First test : one obs. available at each $24 \mathrm{~h}$ !

- DA method chosen to fit PESHMELBA specificities : Deterministic Ensemble Kalman Filter (DEnKF) (Evensen, 1994). Ensemble size $=100$ members

DA used both to correct moisture in vertical profile and to estimate some input parameters: saturated water content $\left(\theta_{\text {sat }}\right)$ on surface

Initial ensemble: perturbation of 145 input parameters. Bounds and distributions are set from field measurements, litterature review or expert knowledge. reduce uncertainty in this spatialized, highly

3. Results Surface moisture in HU4
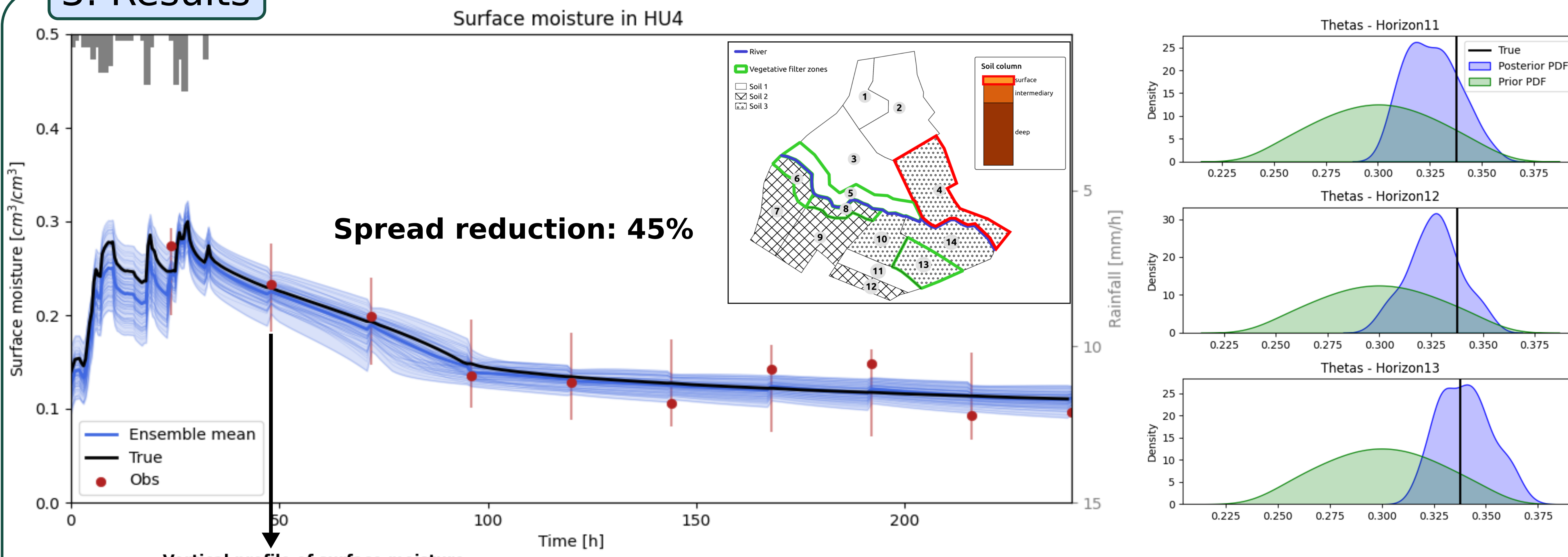

DEnKF quickly decreases both ensemble spread and bias on surface moisture after 3 assimilation cycles (left panel on Figure above). There after, impact of analysis remains quite limited. Joint estimation also significantly improves estimation for surface $\theta$ sat (horizon 11, 12 and 13 , see right panels on Figure above)

However, correction is only significant in first soil horizon $(\sim 1 \mathrm{~cm})$ and does not propagate towards deeper soil horizons (Left Figure). Assimilation of surface moisture images remains of no effect on subsurface.

Next challenge: how to better estimate water and pesticide variables in subsurface?

\section{Conclusion and next steps}

- DEnKF potential to perform joint estimation in the PESHMELBA model is demonstrated using synthetic images. Uncertainty on both surface moisture variables and surface $\theta$ sat parameters is reduced.

- But this setup does not allow for correcting other components of the model (subsurface moisture, pesticide concentration,...). $\rightarrow$ Prospects for improving the process:

1. Smoothing approach instead of filtering approach to better catch the subsurface dynamics

2. Integratin EMI measurements that provide moisture on a vertical profile
[1] Rouzies et al., From agricultural catchment to manaagen
Total Environment, Elsevier, 2019, 671, pp.1144-1160. [2] Buis et al., PALM: a computational framew
John Wiley \& Sons, Ltd., 2006, 18, 231-245

[3] Baghdadi and Zribi. Observation des s
[4] Evensen, Sequential data assim
Oceans $1094.99 .10143-10162$ 